\title{
ESTIMASI POTENSI KARBON PADA SEDIMEN EKOSISTEM MANGROVE DI PESISIR TAMAN NASIONAL BUNAKEN BAGIAN UTARA
}

\author{
(Estimation of Carbon Potential In Mangrove Ecosystem Sediment at Northern of \\ Bunaken National Park Coast)
}
Rio Jonathan Verisandria1 ${ }^{\star}$, Joshian N.W. Schaduw ${ }^{1}$, Calvyn F.A. Sondak ${ }^{1}$, Medy Ompi ${ }^{1}$, Antonius Rumengan ${ }^{1}$, Jety Rangan²

1. Program Studi IImu Kelautan, Fakultas Perikanan dan IImu Kelautan, Universitas Sam Ratulangi, Manado.

2. Program Studi Manajemen Sumberdaya Perairan, Fakultas Perikanan dan IImu Kelautan, Universitas Sam Ratulangi, Manado.

*e-mail : rio_jonathan14@yahoo.com

Mangrove ecosystem is one of the potential parameters to be studied from the blue carbon ecosystem. Mangrove uses carbon dioxide for photosynthesis process and stores it in biomass and sediment stocks as a climate change mitigation effort. Calculating the percentage estimates of carbon stocks in mangrove ecosystems is important because estimates of carbon storage in mangrove ecosystems are so large, especially in mangrove sediments. A study has been conducted to estimate carbon stocks in the sediments of mangrove ecosystems grown at Northern of Bunaken national park coast. Sampling of mangrove sediments was done by purposive sampling techniques and data obtained were analysed by Loss on ignition method. The highest average of soil bulk density value lies in depth $60-100 \mathrm{~cm}$, depth layers at the front and centre respectively of $0,78 \mathrm{~g} / \mathrm{cm}^{3}$ and $0,80 \mathrm{~g} / \mathrm{cm}^{3}$. The back point lies in depth $0-30 \mathrm{~cm}$ about $0,90 \mathrm{~g} / \mathrm{cm}^{3}$. Average value of the highest carbon lies percentage in depth $60-100 \mathrm{~cm}$, front is $20,61 \%$; centre $22,01 \%$, and the back of $16,18 \%$. Average value of carbon deposits in the mangrove ecosystems sediments at Northern of Bunaken national park coast is spread in five locations there are Molas is $126.61 \mathrm{Mg} \mathrm{ha}^{-1}$; Meras is $157.01 \mathrm{Mg} \mathrm{ha}^{-1}$, Tongkaina is 138.26 $\mathrm{Mg} \mathrm{ha}^{-1}$, Bahowo is $40.25 \mathrm{Mg} \mathrm{ha}^{-1}$ and Tiwoho is $136.54 \mathrm{Mg} \mathrm{ha}^{-1}$.

Keywords: Mangrove ecosystem, Carbon estimation, Purpose Sampling, Loss on Ignition

Ekosistem mangrove merupakan salah satu potensi yang menjadi parameter untuk dikaji dari ekosistem Blue Carbon. Mangrove memanfaatkan $\mathrm{CO}_{2}$ untuk proses fotosintesis dan menyimpannya dalam stok biomassa dan sedimen sebagai upaya mitigasi perubahan iklim. Perkiraan penyimpanan karbon pada ekosistem mangrove begitu besar sehingga penting untuk menghitung persentase estimasi simpanan karbon pada ekosistem mangrove terutama pada sedimen mangrove. Telah dilakukan penelitian untuk mengestimasi simpanan karbon pada sedimen ekosistem mangrove yang tumbuh di Pesisir Taman Nasional Bunaken bagian Utara. Pengambilan sampel sedimen mangrove dilakukan dengan teknik Purpose Sampling dan data yang diperoleh dianalisis dengan metode Loss on Ignition. Nilai rata-rata densitas sedimen tanah tertinggi terletak pada lapisan kedalaman $60-100 \mathrm{~cm}$, yaitu pada bagian depan dan tengah masing-masing sebesar $0,78 \mathrm{~g} / \mathrm{cm}^{3}$ dan $0,80 \mathrm{~g} / \mathrm{cm}^{3}$. Pada titik bagian belakang terletak di kedalaman $0-30 \mathrm{~cm}$ yaitu $0,90 \mathrm{~g} / \mathrm{cm}^{3}$. Nilai rata-rata persentase karbon tertinggi terletak pada lapisan kedalaman $60-100 \mathrm{~cm}$, masing-masing bagian depan sebesar 20,61\%; bagian tengah sebesar $22,01 \%$; dan bagian belakang sebesar $16,18 \%$. Nilai rata-rata simpanan karbon pada sedimen ekosistem mangrove di Pesisir Taman Nasional Bunaken bagian Utara tersebar di 5 lokasi, yaitu di Molas sebesar 126,61 $\mathrm{Mg} \mathrm{ha}^{-1}$; di Meras sebesar 157,01 $\mathrm{Mg} \mathrm{ha}^{-1}$; di Tongkaina sebesar 138,26 Mg ha-1; di Bahowo sebesar 40,25 $\mathrm{Mg} \mathrm{ha}^{-1}$; dan di Tiwoho sebesar 136,54 Mg ha $^{-1}$.

Kata kunci: Ekosistem mangrove, Estimasi karbon, Purpose Sampling, Loss on Ignition 


\section{PENDAHULUAN}

Mangrove merupakan salah satu potensi yang menjadi parameter untuk dikaji dari ekosistem karbon biru (Blue Carbon). Menurut Sondak (2015), Blue Carbon atau karbon biru merupakan karbon yang diserap oleh ekosistem pantai seperti mangrove dan lamun dalam hubungan memerangi perubahan iklim global. Peran mangrove dalam kaitannya dengan Blue Carbon lebih ditekankan sebagai upaya mangrove memanfaatkan $\mathrm{CO}_{2}$ untuk proses fotosintesis dan menyimpannya dalam stok biomasa dan sedimen sebagai upaya mitigasi perubahan iklim (Restu et al., 2013).

Pembangunan yang begitu cepat telah memberi dampak negatif terhadap lingkungan, seperti konversi hutan mangrove menjadi tambak dan kawasan pariwisata serta masuknya limbah organik ke perairan pesisir. Aktivitas antropogenik diketahui meningkatkan masukan nutrien anorganik dan karbon organik ke dalam estuari dan perairan pesisir (Gypens et al., 2009 dalam Restu et al., 2013).

Ekosistem mangrove sangat produktif dan berkontribusi sebagai sumber karbon organik dan nutrien lainnya (Alongi et al., 2005 dalam Analuddin et al., 2016). Hutan bakau tropis dan hutan rawa gambut memberikan banyak jasa lingkungan, termasuk siklus hara, perangkap sedimen, perlindungan dari tsunami dan habitat untuk berbagai organisme. Di antara yang paling penting dari fungsi-fungsi tersebut adalah ekosistem mangrove sebagai penyimpan karbon (C).

Perkiraan penyimpanan karbon di ekosistem ini adalah begitu besar sehingga membuat mangrove dan lahan gambut penting untuk mitigasi perubahan iklim. Namun, ekosistem ini sangat rentan terhadap perubahan iklim dan penggunaan lahan (Analuddin et al., 2016).

Menurut Alongi (2012), hutan mangrove adalah hutan yang paling dominan penyimpan karbon dari hutan lainnya, dengan sebagian besar dialokasikan secara proporsional lebih banyak karbon di bawah tanah.

\section{METODE PENELITIAN}

\section{Tempat dan Waktu Penelitian}

Penelitian ini dilakukan selama 2 bulan (April-Juni 2018). Sampel sedimen diambil dari Pesisir Taman Nasional Bunaken Bagian Utara. Lokasi pengambilan sampel dapat dilihat pada Gambar 1.

Selanjutnya analisis sampel dilaksanakan di Laboratorium Analisis Kesehatan, Politeknik Kesehatan Manado, Sulawesi Utara.

\section{Pengambilan dan Penanganan Sampel di Lokasi}

\section{Pengambilan Sampel}

Sampel sedimen diperoleh dari 5 lokasi (Molas, Meras, Tongkaina, Bahowo, Tiwoho) di Pesisir Taman Nasional Bunaken Bagian Utara. Prosedur yang digunakan dalam pengambilan sampel adalah metode survei seperti metode yang dilakukan oleh Mahasani et al (2015), yaitu pengamatan dan pengambilan sampel langsung di lapangan. Pengambilan sampel untuk mengetahui cadangan karbon pada ekosistem mangrove difokuskan pada bahan organik tanah atau sedimen pada ekosistem mangrove yang dilakukan dengan metode Purpose Sampling atau menentukan langsung titik lokasi pengambilan sampel. 


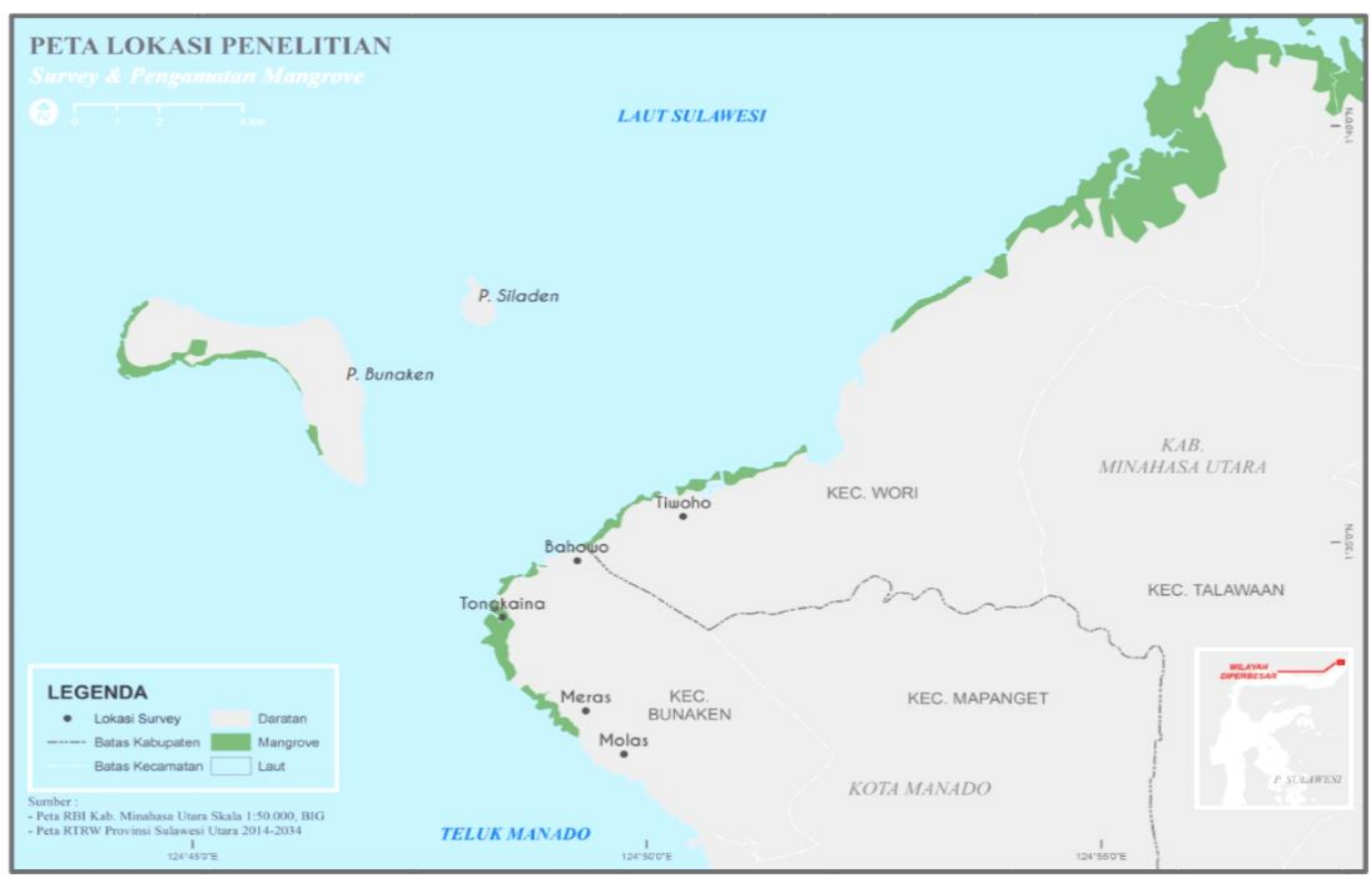

Gambar 1. Lokasi Penelitian Pengambilan Sampel

Pada masing-masing lokasi pengambilan sampel ditentukan 3 (tiga) titik pada ekosistem mangrove yang mewakili bagian depan yaitu lebih dekat ke arah laut (titik pertama), bagian tengah (titik kedua), dan bagian belakang (titik ketiga) bagian yang lebih dekat ke pemukiman untuk mewakili pengambilan sampel pada lokasi. Kemudian pada masing-masing titik diambil 3 sampel berdasarkan kedalaman. Sehingga jumlah sampel yang diperoleh disetiap lokasi sebanyak 9 (sembilan) sampel. Total sampel keseluruhan yang dianalisis adalah 45 sampel.

\section{Penanganan Sampel di Lokasi}

Data yang diperlukan untuk mengestimasi dan persentase karbon organik dalam tanah adalah kedalaman sampel tanah, interval sampel yang diambil dan densitas tanah (kerapatan massa jenis). Untuk mengetahui hal tersebut, tahapan kerja yang perlu dilakukan adalah sebagai berikut:
1. Sebelum melakukan pengambilan sampel, sampah organik dan daun hidup (jika ada) dibersihkan dari permukaan tanah;

2. Kemudian melakukan coring dengan memasukkan corer ke dalam tanah secara vertikal di titik yang telah ditentukan sampai kedalaman mencapai pangkal corer. Corer diputar untuk memotong akar halus yang terdapat dalam tanah. Lalu corer ditarik perlahan dari dalam tanah sambil terus diputar untuk mempertahankan agar sampel sedimen yang diambil tetap penuh dan lengkap;

3. Sampel yang telah diperoleh dibelah secara horizontal, dan dibagi berdasarkan 3 kedalaman (3 sampel), yaitu 0-30 cm, 30-60 $\mathrm{cm}$ dan 60-100 cm. Tidak seluruhnya sampel sedimen diambil, tetapi dengan cara menentukan interval dari kedalaman masing-masing 
sampel tersebut dan sisanya dibuang. Sampel pada kedalaman $0-30 \mathrm{~cm}$ hanya diambil pada kedalaman 10-20 $\mathrm{cm}$, sampel pada kedalaman $30-$ $60 \mathrm{~cm}$ hanya diambil pada kedalaman 40-50 cm dan kedalaman 60-100 cm hanya diambil pada kedalaman $75-85$ $\mathrm{cm}$;

4. Sampel yang diperoleh kemudian dimasukkan ke dalam kantong plastik sampel dan diberi label pada setiap kantong untuk memudahkan identifikasi dan analisis di laboratorium;

5. Sampel tersebut disimpan didalam kulkas agar dapat bertahan sampai pada saatnya dianalisis di laboratorium.

\section{Analisis Sampel dan Pengolahan Data}

\section{Analisis Sampel di Laboratorium}

Setelah pengambilan sampel di lokasi selesai, kemudian sampel yang diperoleh dianalisis di laboratorium dengan metode loss on ignition (LOI) (Howard, J et al., 2014 dalam Mahasani et al., 2015). Tahapan analisis tersebut adalah:

1. Sampel sedimen yang diperoleh ditempatkan dalam cawan porcelain. Kemudian dikeringkan di dalam oven dengan suhu $60^{\circ} \mathrm{C}$ selama 48 jam;

2. Setelah sampel kering kemudian digerus atau dihaluskan dengan menggunakan mortar agar kondisi setiap sampel menjadi homogen. Kemudian setiap sampel yang sudah dihaluskan tersebut ditempatkan kembali kedalam kantong plastik sampel;
3. Sampel tersebut kemudian diambil dengan sendok kecil dan ditimbang sebanyak 3 gram dan ditempatkan pada crucible porcelain. Sampel tersebut dimasukkan ke dalam muffle furnace dan dibakar dengan suhu $450^{\circ} \mathrm{C}$ selama 4 jam. Kemudian sampel tersebut ditimbang kembali dan hasilnya di catat.

\section{Pengolahan Data}

Data yang dihitung adalah kedalaman sampel sedimen, densitas tanah, densitas karbon, estimasi karbon dan persentase karbon organik pada sedimen. Adapun perhitungan yang digunakan dalam menganalisis data sebagai berikut (Howard et al., 2014 dalam Mahasani et al., 2015):

1. Densitas tanah tanah merupakan berat partikel per satuan volume tanah beserta porinya. Rumus yang digunakan untuk menghitung densitas tanah (BD) disajikan pada persamaan 1:

Densitas Tanah :

$\left(\mathrm{g} / \mathrm{cm}^{3}\right)=\frac{\text { oven }- \text { dry mass }(\mathrm{g})}{\text { sample volume }\left(\mathrm{cm}^{3}\right)}$

Oven-dry mass = Massa sampel yang dikeringkan (gram)

Sample volume = Volume sampel $\left(\mathrm{cm}^{3}\right)$

2. Pengabuan Kering (loss on ignition) dihitung menggunakan persamaan 2:

$\%$ BO $=\left(\frac{\mathrm{Wo}-\mathrm{Wt}}{\mathrm{Wo}} \times 100\right)$

$\% \mathrm{BO}=$ Persentase bahan organik sedimen yang hilang pada proses pembakaran.

Wo = Berat awal (3 gram).

$\mathrm{Wt}=$ Berat akhir setelah pembakaran (gram).

3. Konversi persentase bahan organik menjadi persentase karbon dihitung menggunakan persamaan 3:

$\% \mathrm{C}=(1 / 1,724) \mathrm{X} \% \mathrm{BO}$ 
$\% \mathrm{C}=$ Kandungan karbon bahan sedimen organik.

$1,724=$ Konstanta untuk mengkonversi \% bahan organik menjadi \% C organik.

4. Densitas karbon (C) dihitung dengan menggunakan persamaan 4:

Soil $C$ density $\left(\mathrm{g} \mathrm{C} \mathrm{cm}^{-3}\right)=$

$\% \mathrm{C} \times \mathrm{BD}$ (densitas tanah)

Soil $C$ density=Densitas Karbon

5. Kandungan karbon pada tanah diestimasi dengan persamaan 5:

Soil $C\left(\mathrm{Mg} \mathrm{ha}^{-1}\right)=$

BD x SDI(Soil Depth Interval) x \%C ...(5)

Soil $\mathrm{C}=$ Estimasi simpanan karbon.

$\mathrm{SDI}=$ Interval kedalaman sampel (cm).

\section{HASIL DAN PEMBAHASAN}

\section{Densitas Tanah}

Densitas tanah merupakan bobot massa tanah pada kondisi yang telah dikering-ovenkan per satuan volume. Dari hasil analisis, diketahui bahwa tanah pada masing-masing kedalaman memiliki nilai densitas tanah yang berbeda. Volume sampel diperoleh dari hasil pengukuran tinggi interval sampel dan diameter corer.

Nilai densitas tanah di masingmasing kedalaman disetiap titik berbeda. Nilai rata-rata densitas tanah disetiap lapisan kedalaman seluruh lokasi dapat dilihat pada Gambar 2.

Terlihat nilai rata-rata densitas tanah tertinggi terdapat pada lapisan kedalaman $60-100 \mathrm{~cm}$ yaitu pada titik bagian depan dan tengah, masingmasing sebesar $0,78 \mathrm{~g} / \mathrm{cm}^{3}$ dan 0,80 $\mathrm{g} / \mathrm{cm}^{3}$. Sedangkan pada bagian belakang nilai rata-rata densitas tanah tertinggi terletak pada lapisan kedalaman $0-30 \mathrm{~cm}$ yaitu sebesar 0,90 $\mathrm{g} / \mathrm{cm}^{3}$. Namun untuk keseluruhan nilai rata-rata densitas tanah disetiap kedalaman tidak jauh berbeda.

Nilai densitas tanah pada setiap lapisan kedalaman sedimen akan memiliki nilai yang berbeda tergantung pada lokasi titik pengambilan sampel dan jenis vegetasi yang tumbuh di atasnya (Mahasani et al., 2015).

Nilai densitas tanah pada kawasan hutan mangrove ini masih tergolong rendah dibandingkan hutan terestrial lainnya. Nilai densitas tanah

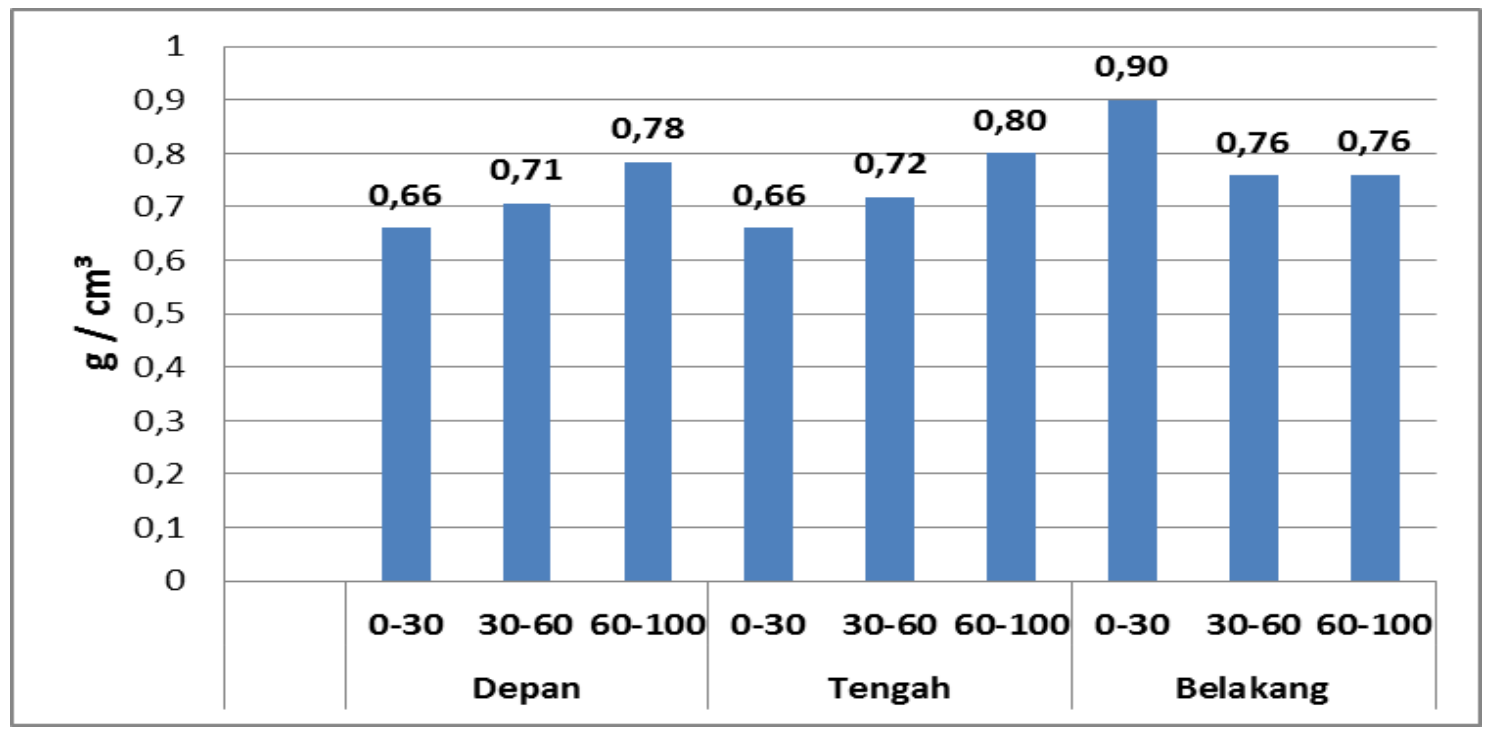

Gambar 2. Grafik nilai rata-rata densitas tanah. 
yang diperoleh dari penelitian ini lebih kecil dibandingkan dengan nilai densitas tanah yang diperoleh dari hasil penelitian stok karbon tanah yang dilakukan oleh Edwin (2016) pada perkebunan karet dan lada yaitu sebesar 1,26 g/ $\mathrm{cm}^{3}$. Hal ini dikarenakan penyusun partikel tanah mangrove didominasi pasir berlumpur sehingga kemampuan menahan air yang sangat rendah dan kerapatan tanah juga akan rendah (Edwin, 2016).

Nilai densitas tanah yang diperoleh dari penelitian ini lebih besar dibandingkan dengan nilai densitas tanah yang diperoleh dari hasil penelitian yang dilakukan di hutan mangrove bekas tambak di Bali (Mahasani et al., 2015) yaitu sebesar $0,139 \mathrm{~g} / \mathrm{cm}^{3}$. Hal ini dikarenakan adanya perbedaan interval yang digunakan dalam pengambilan sampel sedimen. Interval yang digunakan pada penelitian di hutan mangrove bekas tambak di Bali, yaitu $5 \mathrm{~cm}$.

\section{Karbon Organik pada Sedimen}

Karbon organik merupakan salah satu penyusun senyawa organik di perairan. Menurut Latifa et al (2013), karbon organik mempunyai fungsi untuk menciptakan kesuburan tanah dan merupakan unsur hara bagi tanaman.

Perolehan nilai persentase karbon organik didapatkan dari hasil pengabuan untuk mengetahui bahan organik dan dikonversi menjadi karbon organik. Nilai rata-rata persentase karbon organik seluruh lokasi pada masing-masing kedalaman dapat dilihat pada Gambar 3.

Dari Gambar 3, dapat dilihat bahwa nilai rata-rata persentase karbon organik tertinggi terletak pada lapisan kedalaman 60-100 cm disetiap titik pengambilan sampel. pada titik bagian depan yaitu $20,61 \%$, pada titik bagian tengah yaitu $22,01 \%$ dan pada titik bagian belakang yaitu $16,18 \%$.

Nilai persentase karbon organik pada penelitian ini lebih besar dibandingkan dengan persentase karbon organik pada penelitian yang dilakukan oleh Edwin (2016) di perkebunan karet Kalimantan Timur yaitu 2,5\% dan terletak pada bagian dalam tanah. Hal ini menunjukkan bahwa kandungan karbon organik pada sedimen mangrove lebih besar dibandingkan sedimen tanah perkebunan karet.

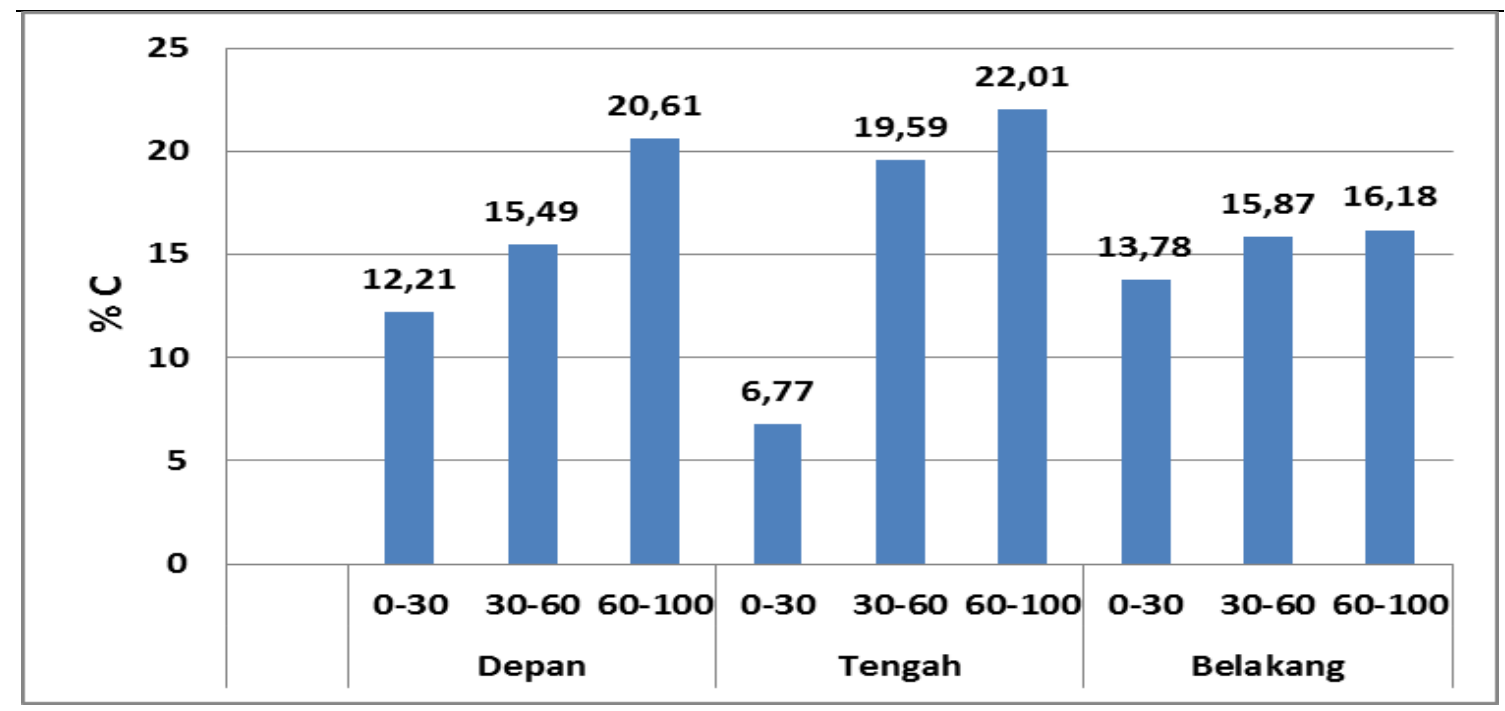

Gambar 3. Grafik nilai rata-rata persentase karbon organik. 
Perbandingan dengan penelitian lainnya mengenai nilai persentase karbon organik sedimen yaitu pada penelitian yang dilakukan oleh Nofitasari et al. (2017) di ekosistem lamun Kabupaten Bintan dengan nilai persentase karbon organik tertinggi yang diperoleh yaitu $14,35 \%$.

Hasil yang diperoleh menunjukkan semakin dalam kandungan karbon organik sedimen semakin meningkat. Hal ini dipengaruhi oleh banyaknya akar yang diperoleh pada bagian paling dalam saat pengambilan sampel.

Menurut Mahasani et al (2016), Akar merupakan salah satu bahan organik yang ada di dalam tanah dan diduga berperan dalam menyumbangkan kandungan karbon organik di dalam tanah.

Menurut Madjid (2007) dalam Dewanti et al (2016), sumber primer bahan organik tanah berasal dari jaringan organik tanaman yang dapat berupa daun, ranting dan cabang, batang, buah dan akar.

\section{Potensi Karbon Total Sedimen Mangrove}

\section{Potensi Karbon Kelurahan Molas}

Pengambilan sampel sedimen di Kelurahan Molas dilakukan pada siang hari dengan kondisi cuaca mendung. Jenis sedimen tanah di lokasi ini pasir berlumpur dan hutan mangrove di kawasan ini cukup rapat. Pengambilan sampel dilakukan pada 3 (tiga) titik, yaitu bagian terdepan hutan mangrove dengan titik koordinat N: 1032'14.712" dan E: $124^{\circ} 49^{\prime} 36.282^{\prime \prime}$, bagian tengah dengan titik koordinat N: $1^{\circ} 32$ '15.4824" dan E: $124^{\circ} 49^{\prime} 36.5376^{\prime \prime}$ dan bagian belakang dengan titik koordinat $\mathrm{N}$ : 1032'16.2204" dan E: 124²9'37.5852". Estimasi potensi karbon di kawasan ini dapat dilihat pada Tabel 1.

Dari data analisis pada Tabel 1 dapat dilihat bahwa kandungan karbon pada lapisan kedalaman 60-100 cm lebih banyak dibandingkan dengan lapisan kedalaman lainnya di setiap titik. Pada titik bagian depan dengan kedalaman 60-100 cm memiliki kandungan karbon sebesar 186,80 $\mathrm{Mg} \mathrm{ha}^{-1}$. Pada titik bagian tengah dengan kedalaman 60 $100 \mathrm{~cm}$ memiliki kandungan karbon sebesar 240,68 $\mathrm{Mg} \mathrm{ha}^{-1}$. Pada titik bagian belakang dengan kedalaman 60-100 cm memiliki kandungan karbon sebesar 152,54 $\mathrm{Mg} \mathrm{ha}^{-1}$.

\section{Potensi Karbon Kelurahan Meras}

Pengambilan sampel sedimen di Kelurahan Meras dilakukan pada siang hari dengan kondisi cuaca hujan ringan. Jenis sedimen tanah di lokasi ini pasir berlumpur dan hutan mangrove di kawasan ini sangat rapat. Pengambilan sampel dilakukan di 3 (tiga) titik, yaitu bagian depan hutan mangrove dengan titik koordinat $\mathrm{N}$ : $1^{\circ} 33^{\prime} 3.5568$ " dan $\mathrm{E}$ : 1244'ㅇ.3964", bagian tengah dengan titik koordinat $\mathrm{N}$ : $1^{\circ} 33^{\prime} 6.0732$ dan E: 124\%4'54.288" dan bagian belakang dengan titik koordinat $\mathrm{N}$ : 1033'8.118" dan E: 124²8'55.6128". Estimasi potensi karbon di kawasan ini dapat dilihat pada Tabel 2. 
Tabel 1. Hasil analisis sampel Kelurahan Molas

\begin{tabular}{|c|c|c|c|c|c|c|c|c|c|}
\hline Titik & $\begin{array}{l}\text { Kedalaman } \\
\text { (cm) }\end{array}$ & $\begin{array}{c}\text { Berat } \\
\text { Kering } \\
(\mathrm{g})\end{array}$ & $\begin{array}{c}\text { Sebelum } \\
\text { pembak } \\
\text { aran (3 } \\
\text { g) }\end{array}$ & $\begin{array}{l}\text { Setelah } \\
\text { pembak } \\
\text { aran (g) }\end{array}$ & $\begin{array}{c}\text { Bulk } \\
\text { Density } \\
\left(\mathbf{g} / \mathrm{cm}^{3}\right)\end{array}$ & $\%$ BO & $\% \mathrm{C}$ & $\begin{array}{c}\text { Densitas } \\
\text { karbon }(\mathrm{g} \\
\left.\mathrm{C} \mathrm{cm}^{-3}\right)\end{array}$ & $\begin{array}{c}\text { Karbon } \\
\text { total(Mg } \\
\left.\text { ha }^{-1}\right)\end{array}$ \\
\hline \multirow{3}{*}{ Depan } & $0-30$ & 133,6 & 3 & 2,3318 & 0,68 & 22,27 & 12,92 & 8,80 & 87,95 \\
\hline & $30-60$ & 131,1 & 3 & 2,3544 & 0,67 & 21,52 & 12,48 & 8,34 & 83,39 \\
\hline & $60-100$ & 142,9 & 3 & 1,6732 & 0,73 & 44,23 & 25,65 & 18,68 & 186,80 \\
\hline \multirow{3}{*}{ Tengah } & $0-30$ & 106,7 & 3 & 2,8531 & 0,54 & 4,90 & 2,84 & 1,54 & 15,44 \\
\hline & $30-60$ & 119,6 & 3 & 1,6715 & 0,61 & 44,28 & 25,69 & 15,65 & 156,54 \\
\hline & $60-100$ & 147,9 & 3 & 1,3483 & 0,75 & 55,06 & 31,94 & 24,07 & 240,68 \\
\hline \multirow{3}{*}{ Belakang } & $0-30$ & 155,9 & 3 & 2,1523 & 0,79 & 28,26 & 16,39 & 13,02 & 130,20 \\
\hline & $30-60$ & 144,2 & 3 & 2,3948 & 0,73 & 20,17 & 11,70 & 8,60 & 85,98 \\
\hline & $60-100$ & 133,8 & 3 & 1,8428 & 0,68 & 38,57 & 22,37 & 15,25 & 152,54 \\
\hline
\end{tabular}

Tabel 2. Hasil analisis sampel Kelurahan Meras

\begin{tabular}{|c|c|c|c|c|c|c|c|c|c|}
\hline Titik & $\begin{array}{l}\text { Kedalaman } \\
\text { (cm) }\end{array}$ & $\begin{array}{l}\text { Berat } \\
\text { Kering } \\
(\mathrm{g})\end{array}$ & $\begin{array}{c}\text { Sebelum } \\
\text { pembak } \\
\text { aran (3 } \\
\text { g) }\end{array}$ & $\begin{array}{l}\text { Setelah } \\
\text { pembak } \\
\text { aran (g) }\end{array}$ & $\begin{array}{c}\text { Bulk } \\
\text { Density } \\
\left(\mathrm{g} / \mathrm{cm}^{3}\right)\end{array}$ & $\%$ BO & $\% \mathrm{C}$ & $\begin{array}{c}\text { Densitas } \\
\text { karbon }(\mathrm{g} \\
\left.\mathrm{C} \mathrm{cm}^{-3}\right)\end{array}$ & $\begin{array}{c}\text { Karbon } \\
\text { total }\end{array}$ \\
\hline \multirow{3}{*}{ Depan } & $0-30$ & 139,2 & 3 & 2,1718 & 0,71 & 27,38 & 15,88 & 11,26 & 112,63 \\
\hline & $30-60$ & 144,4 & 3 & 2,4402 & 0,74 & 18,66 & 10,82 & 7,96 & 79,64 \\
\hline & $60-100$ & 146,9 & 3 & 1,7617 & 0,75 & 41,28 & 23,94 & 17,92 & 179,22 \\
\hline \multirow{3}{*}{ Tengah } & $0-30$ & 129,6 & 3 & 2,7801 & 0,66 & 7,33 & 4,25 & 2,81 & 28,08 \\
\hline & $30-60$ & 139,1 & 3 & 1,322 & 0,71 & 55,93 & 32,44 & 23,00 & 229,96 \\
\hline & $60-100$ & 168,6 & 3 & 1,4602 & 0,86 & 51,33 & 29,77 & 25,58 & 255,77 \\
\hline \multirow{3}{*}{ Belakang } & $0-30$ & 186,6 & 3 & 1,8687 & 0,95 & 31,71 & 21,87 & 20,80 & 207,98 \\
\hline & $30-60$ & 139,1 & 3 & 1,5722 & 0,71 & 47,59 & 27,61 & 19,57 & 195,67 \\
\hline & $60-100$ & 129,6 & 3 & 2,0281 & 0,66 & 32,40 & 18,79 & 12,41 & 124,10 \\
\hline
\end{tabular}


Dari data analisis Tabel 2, di masing-masing titik kandungan karbon terbanyak terdapat pada lapisan kedalaman 60-100 cm untuk titik bagian depan dan tengah yaitu sebesar 179,22 Mg ha ${ }^{-1}$ dan 255,77 Mg ha ${ }^{-1}$. Sedangkan kandungan karbon terbanyak di titik bagian belakang terdapat pada lapisan kedalaman 0-30 $\mathrm{cm}$ yaitu sebesar 207,98 $\mathrm{Mg} \mathrm{ha}^{-1}$.

\section{Potensi Karbon Kelurahan Tongkaina}

Pengambilan sampel sedimen di Tongkaina dilakukan pada pagi hari dengan kondisi cuaca hujan ringan. Jenis sedimen tanah di lokasi ini pasir berlumpur dan hutan mangrove di kawasan ini cukup rapat.

Pengambilan sampel dilakukan di 3 (tiga) titik berbeda, yaitu bagian terdepan dengan titik koordinat $\mathrm{N}$ :
1034'14.0628" dan E: 124²4'17.2224", bagian tengah dengan titik koordinat $\mathrm{N}$ : 1034'14.1024" dan E: 12448'17.7264 dan pada bagian belakang dengan titik koordinat $\mathrm{N}$ : 1034'13.7712" dan $\mathrm{E}$ : 12448'20.3688". Estimasi potensi karbon di kawasan ini dapat dilihat pada Tabel 3.

Dari data analisis Tabel 3 , di masing-masing titik tengah dan belakang memiliki kandungan karbon terbanyak terdapat pada lapisan kedalaman 60-100 cm yaitu masingmasing sebesar 163,73 $\mathrm{Mg} \mathrm{ha}^{-1}$ dan $121,92 \mathrm{Mg} \mathrm{ha}^{-1}$. Sedangkan kandungan karbon terbanyak di titik bagian depan terdapat pada lapisan kedalaman 30-60 $\mathrm{cm}$ yaitu sebesar 202,75 Mg ha-1.

Tabel 3. Hasil analisis sampel Kelurahan Tongkaina.

\begin{tabular}{|c|c|c|c|c|c|c|c|c|c|}
\hline Titik & $\begin{array}{l}\text { Kedalaman } \\
\quad(\mathrm{cm})\end{array}$ & $\begin{array}{c}\text { Berat } \\
\text { Kering } \\
\text { (g) }\end{array}$ & $\begin{array}{c}\text { Sebelum } \\
\text { pembaka } \\
\text { ran }(3 \mathrm{~g})\end{array}$ & $\begin{array}{l}\text { Setelah } \\
\text { pembak } \\
\text { aran (g) }\end{array}$ & $\begin{array}{c}\text { Bulk } \\
\text { Density } \\
\left(\mathbf{g} / \mathrm{cm}^{3}\right)\end{array}$ & $\%$ BO & $\% \mathrm{C}$ & $\begin{array}{c}\text { Densitas } \\
\operatorname{karbon}(\mathbf{g} \\
\left.\mathrm{C} \mathrm{cm}^{-3}\right)\end{array}$ & $\begin{array}{c}\text { Karbon } \\
\text { total } \\
\left(\mathrm{Mg} \mathrm{ha}^{-1}\right)\end{array}$ \\
\hline \multirow{3}{*}{ Depan } & $0-30$ & 123,7 & 3 & 1,9859 & 0,63 & 33,80 & 19,61 & 12,36 & 123,59 \\
\hline & $30-60$ & 163,2 & 3 & 1,739 & 0,83 & 42,03 & 24,38 & 20,28 & 202,75 \\
\hline & $60-100$ & 153,5 & 3 & 1,8497 & 0,78 & 38,34 & 22,24 & 17,40 & 173,96 \\
\hline \multirow{3}{*}{ Tengah } & $0-30$ & 138,3 & 3 & 2,2565 & 0,70 & 24,78 & 14,38 & 10,13 & 101,31 \\
\hline & $30-60$ & 128,2 & 3 & 1,8914 & 0,65 & 36,95 & 21,43 & 14,00 & 140,02 \\
\hline & $60-100$ & 148,7 & 3 & 1,8824 & 0,76 & 37,25 & 21,61 & 16,37 & 163,73 \\
\hline \multirow{3}{*}{ Belakang } & $0-30$ & 189,5 & 3 & 2,4629 & 0,97 & 17,90 & 10,38 & 10,03 & 100,28 \\
\hline & $30-60$ & 146,5 & 3 & 2,1906 & 0,75 & 26,98 & 15,65 & 11,68 & 116,82 \\
\hline & $60-100$ & 175,4 & 3 & 2,2945 & 0,89 & 23,52 & 13,64 & 12,19 & 121,92 \\
\hline
\end{tabular}




\section{Potensi Karbon di Bahowo}

Pengambilan sampel sedimen di Bahowo dilakukan pada siang hari dengan kondisi cuaca cerah.

Jenis sedimen tanah di lokasi ini pasir berlumpur dan hutan mangrove di kawasan ini cukup rapat. Pengambilan sampel dilakukan di 3 (tiga) titik berbeda, yaitu bagian terdepan dengan titik koordinat N: 1034'56.3556" dan E: 124'49'9.0228", bagian tengah dengan titik koordinat N: 1'34'54.3396" dan E:

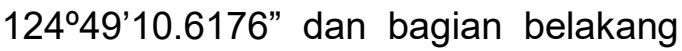

dengan titik koordinat N: $1^{\circ} 34^{\prime} 52.8564^{\prime \prime}$ dan E: 124\%49'11.0676. Estimasi potensi karbon di kawasan ini dapat dilihat pada Tabel 4.

Dari data analisis Tabel 4, di masing-masing titik tengah dan belakang memiliki kandungan karbon terbanyak terdapat pada lapisan kedalaman 30-60 cm yaitu masingmasing sebesar 56,59 $\mathrm{Mg} \mathrm{ha}^{-1}$ dan $52,07 \mathrm{Mg} \mathrm{ha}^{-1}$. Sedangkan kandungan karbon terbanyak di titik bagian depan terdapat pada lapisan kedalaman 60$100 \mathrm{~cm}$ yaitu sebesar $58,21 \mathrm{Mg} \mathrm{ha}^{-1}$.

Tabel 4. Hasil analisis sampel Desa Bahowo.

\begin{tabular}{|c|c|c|c|c|c|c|c|c|c|}
\hline Titik & $\begin{array}{l}\text { Kedalaman } \\
\quad(\mathrm{cm})\end{array}$ & $\begin{array}{l}\text { Berat } \\
\text { Kering } \\
(g)\end{array}$ & $\begin{array}{c}\text { Sebelum } \\
\text { pembaka } \\
\text { ran }(3 \mathrm{~g})\end{array}$ & $\begin{array}{c}\text { Setelah } \\
\text { pemba } \\
\text { karan } \\
(\mathrm{g})\end{array}$ & $\begin{array}{c}\text { Bulk } \\
\text { Density } \\
\left(\mathbf{g} / \mathrm{cm}^{3}\right)\end{array}$ & $\%$ BO & $\% \mathrm{C}$ & 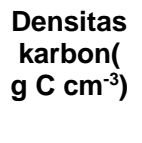 & $\begin{array}{c}\text { Karbon } \\
\text { total(Mg } \\
\left.\text { ha }^{-1}\right)\end{array}$ \\
\hline \multirow{3}{*}{ Depan } & $0-30$ & 129,7 & 3 & 2,9194 & 0,66 & 2,69 & 1,56 & 1,03 & 10,30 \\
\hline & $30-60$ & 128,6 & 3 & 2,7328 & 0,66 & 8,91 & 5,17 & 3,39 & 33,85 \\
\hline & $60-100$ & 158,1 & 3 & 2,6263 & 0,81 & 12,46 & 7,23 & 5,82 & 58,21 \\
\hline \multirow{3}{*}{ Tengah } & $0-30$ & 121,9 & 3 & 2,8436 & 0,62 & 5,21 & 3,02 & 1,88 & 18,78 \\
\hline & $30-60$ & 136,7 & 3 & 2,5798 & 0,70 & 14,01 & 8,12 & 5,66 & 56,59 \\
\hline & $60-100$ & 136,6 & 3 & 2,6304 & 0,70 & 12,32 & 7,15 & 4,97 & 49,74 \\
\hline \multirow{3}{*}{ Belakang } & $0-30$ & 172,7 & 3 & 2,7836 & 0,88 & 7,21 & 4,18 & 3,68 & 36,82 \\
\hline & $30-60$ & 137,7 & 3 & 2,6162 & 0,70 & 12,79 & 7,42 & 5,21 & 52,07 \\
\hline & $60-100$ & 158 & 3 & 2,7052 & 0,81 & 9,83 & 5,70 & 4,59 & 45,89 \\
\hline
\end{tabular}




\section{Potensi Karbon di Tiwoho}

Pengambilan sampel sedimen di Tiwoho dilakukan pada sore hari dengan kondisi cuaca hujan ringan.

Jenis sedimen tanah di lokasi ini pasir berlumpur dan kerikil. Hutan mangrove di kawasan ini cukup rapat dan terdapat didekat muara sungai. Pengambilan sampel dilakukan di 3 (tiga) titik berbeda, yaitu bagian terdepan dengan titik koordinat $\mathrm{N}$ : 1³5'38.2992" dan E: 12450'14.0604, bagian tengah dengan titik koordinat $\mathrm{N}$ : 1³5'35.6568" dan E: 12450'13.5564" dan bagian belakang dengan titik koordinat $\mathrm{N}$ : 1035'33.5112" dan $\mathrm{E}$ : 12450'12.9012". Estimasi potensi karbon di kawasan ini dapat dilihat pada Tabel 5. Dapat dilihat bahwa kandungan karbon pada lapisan kedalaman 60-100 cm lebih banyak dibandingkan dengan lapisan kedalaman lainnya di setiap titik. Pada titik bagian depan dengan kedalaman 60-100 cm memiliki kandungan karbon sebesar 203,65 Mg ha ${ }^{-1}$. Pada titik bagian tengah dengan kedalaman $60-$ $100 \mathrm{~cm}$ memiliki kandungan karbon sebesar 181,39 Mg ha1. Pada titik bagian belakang dengan kedalaman 60-100 cm memiliki kandungan karbon sebesar 154,05 $\mathrm{Mg} \mathrm{ha}^{-1}$.

\section{Rata-rata Kandungan Karbon pada Masing-Masing Kedalaman}

Nilai rata-rata kandungan karbon yang diperoleh pada masing-masing lapisan kedalaman disetiap titik berbeda untuk semua lokasi. Nilai ratarata kandungan karbon masing-masing kedalaman dapat dilihat pada Gambar 4.

Tabel 5. Hasil analisis sampel Desa Tiwoho..

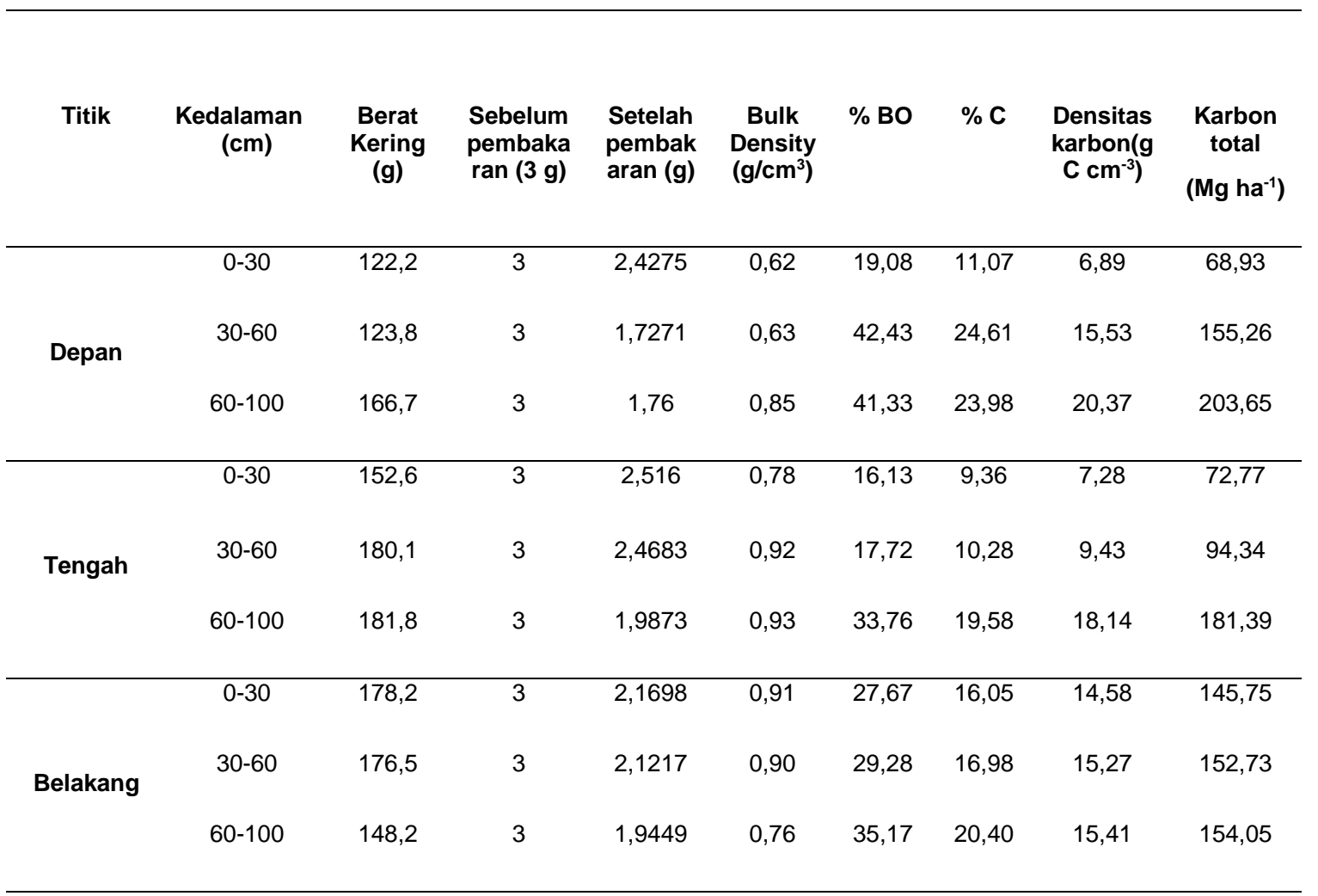




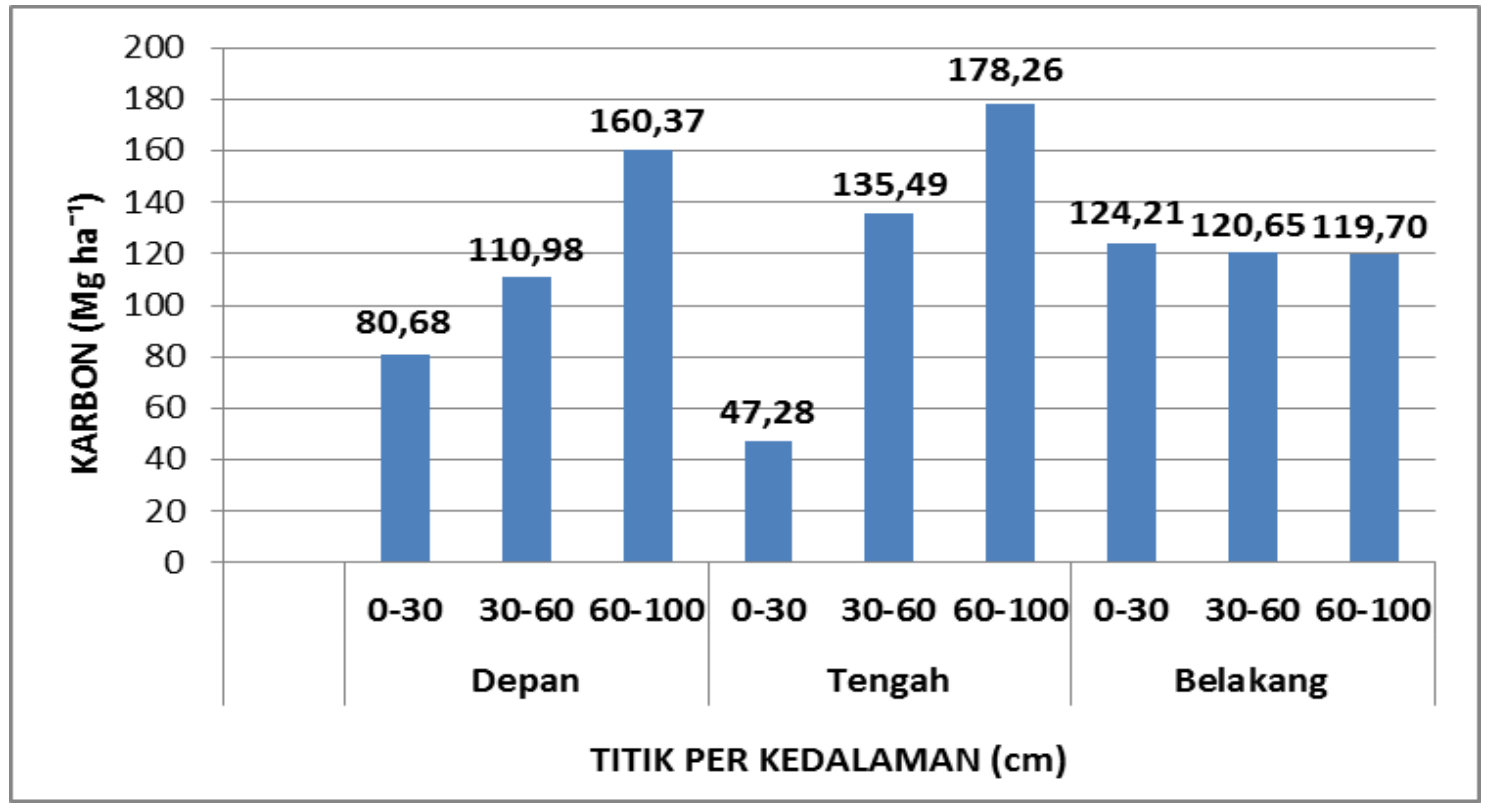

Gambar 4. Grafik rata-rata kandungan karbon per kedalaman.

Pada Gambar 4 dapat dilihat, titik bagian depan dan tengah nilai ratarata kandungan karbon terbanyak terdapat pada lapisan kedalaman 60$100 \mathrm{~cm}$, yaitu masing-masing sebesar $160,37 \mathrm{Mg} \mathrm{ha}^{-1}$ dan $178,26 \mathrm{Mg} \mathrm{ha}^{-1}$. Sedangkan pada titik bagian belakang nilai rata-rata kandungan karbon terbanyak terdapat pada lapisan kedalaman 0-30 cm, yaitu sebesar $124,21 \mathrm{Mg} \mathrm{ha}^{-1}$.

Nilai rata-rata kandungan karbon pada titik bagian depan dan tengah memperlihatkan bahwa semakin dalam semakin meningkat kandungan karbon. Sedangkan pada titik bagian belakang memperlihatkan hasil yang sebaliknya, yaitu semakin ke dalam kandungan karbon semakin kecil.

Pada titik bagian belakang, nilai rata-rata kandungan karbon terbanyak terdapat pada lapisan kedalaman 0-30 $\mathrm{cm}$. Perbedaan nilai rata-rata kandungan karbon pada bagian belakang tidak terlalu jauh. Kondisi ini dikarenakan pada bagian belakang lebih dekat dari pemukiman yang langsung menerima buangan atau inputan dari daratan menuju laut yang disaring terlebih dahulu oleh ekosistem mangrove.

Menurut Heriyanto dan Subiandono (2016), buangan dari daratan berupa sampah organik maupun anorganik yang terendapkan di dalam sedimen dapat mempengaruhi tingkat kesuburan sedimen. Sedimen yang subur kaya akan kandungan organik dapat meningkatkan kandungan karbon organik pada sedimen.

\section{Rata-rata Kandungan Karbon Total pada Masing-masing Lokasi}

Distribusi nilai rata-rata kandungan karbon pada masingmasing lokasi berbeda. Hal ini dipengaruhi oleh kondisi densitas tanah yang telah dianalisis dan tutupan kanopi mangrove masing-masing lokasi. Nilai rata-rata kandungan karbon pada masing-masing lokasi dapat dilihat pada Gambar 5. 


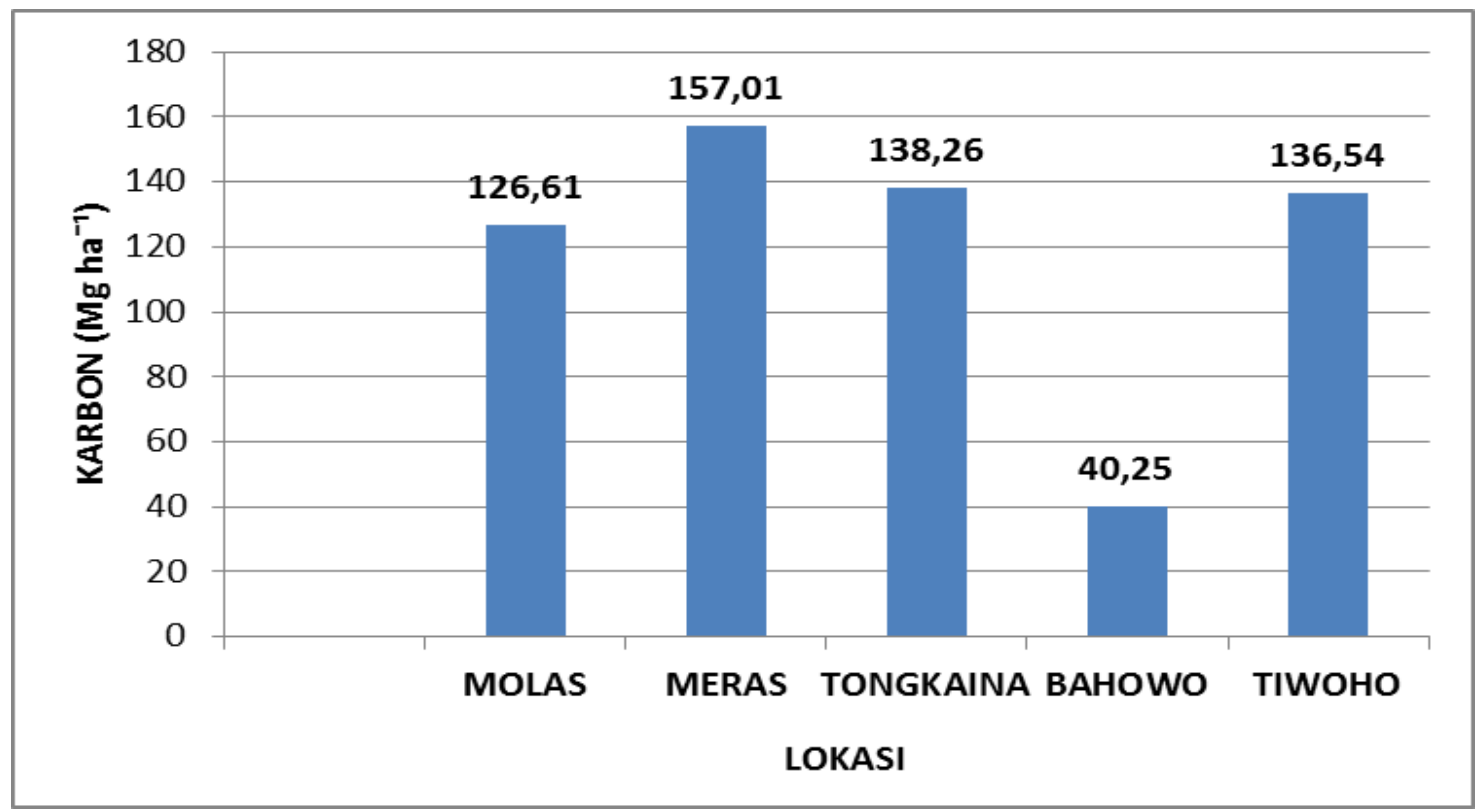

Gambar 5. Grafik rata-rata kandungan karbon total setiap lokasi.

Nilai rata-rata kandungan karbon total terbanyak terdapat pada lokasi Meras yaitu sebesar 157,01 $\mathrm{Mg} \mathrm{ha}^{-1}$, diikuti pada lokasi Tongkaina sebesar

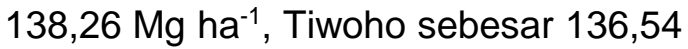
$\mathrm{Mg} \mathrm{ha}^{-1}$, Molas sebesar 126,61 $\mathrm{Mg} \mathrm{ha}^{-1}$ dan nilai rata-rata kandungan karbon paling sedikit terdapat pada lokasi Bahowo yaitu sebesar 40,25 Mg ha-1.

Tinggi rendahnya kandungan karbon dalam tanah ditentukan dari nilai kepadatan sedimen tanah dan kedalaman tanah pada masing-masing sampel. semakin tebal kepadatan tanah akan semakin tinggi cadangan karbon pada lahan tersebut (Hooijer et al 2006 dalam Prayitno et al 2013).

Kandungan karbon total pada sedimen tanah ekosistem mangrove Taman Nasional Bunaken Bagian Utara yang diperoleh berkisar antara 40,25 $\mathrm{Mg} \mathrm{ha}^{-1}$ hingga 157,01 $\mathrm{Mg} \mathrm{ha}^{-1}$. Hasil yang diperoleh ini cukup kecil dibandingkan dengan hasil penelitian Mahasani et al., (2016) di Hutan Mangrove Taman Hutan Raya Ngurah Rai, Bali yaitu berkisar antara 83,046 Mg ha ${ }^{-1}$ hingga $216,168 \mathrm{Mg} \mathrm{ha}^{-1}$ dan hasil penelitian Syukri (2017) yaitu berkisar 53,09 Mg ha-1 hingga 196,39
$\mathrm{Mg} \mathrm{ha}^{-1}$. Namun hasil penelitian ini lebih besar dari hasil penelitian lain yang dilakukan oleh Suryono et al (2018) di Hutan Mangrove Perancak Jembrana Bali, memperoleh nilai kandungan karbon sebesar 57,699 $\mathrm{Mg} \mathrm{ha}^{-1}$.

Perbedaan nilai kandungan karbon total sedimen mangrove dikarenakan kondisi tutupan mangrove disetiap lokasi yang berbeda, jenis mangrove yang tumbuh disetiap lokasi, dan juga struktur karakteristik sedimen tanah disetiap lokasi (Suryono et al., 2018).

Menurut Syukri (2017), tingginya nilai tutupan kanopi mangrove berbanding lurus dengan kandungan biomassa sedimen. Semakin tinggi kandungan biomassa, kandungan karbon pada sedimen juga akan meningkat.

Perbedaan nilai kandungan karbon pada masing-masing lokasi didukung dengan data hasil penelitian yang dilakukan Anthoni et al (2017) tentang nilai persentase tutupan kanopi mangrove di pesisir Taman Nasional Bunaken bagian Utara. Data persentase tutupan kanopi mangrove dapat dilihat pada Gambar 6. 


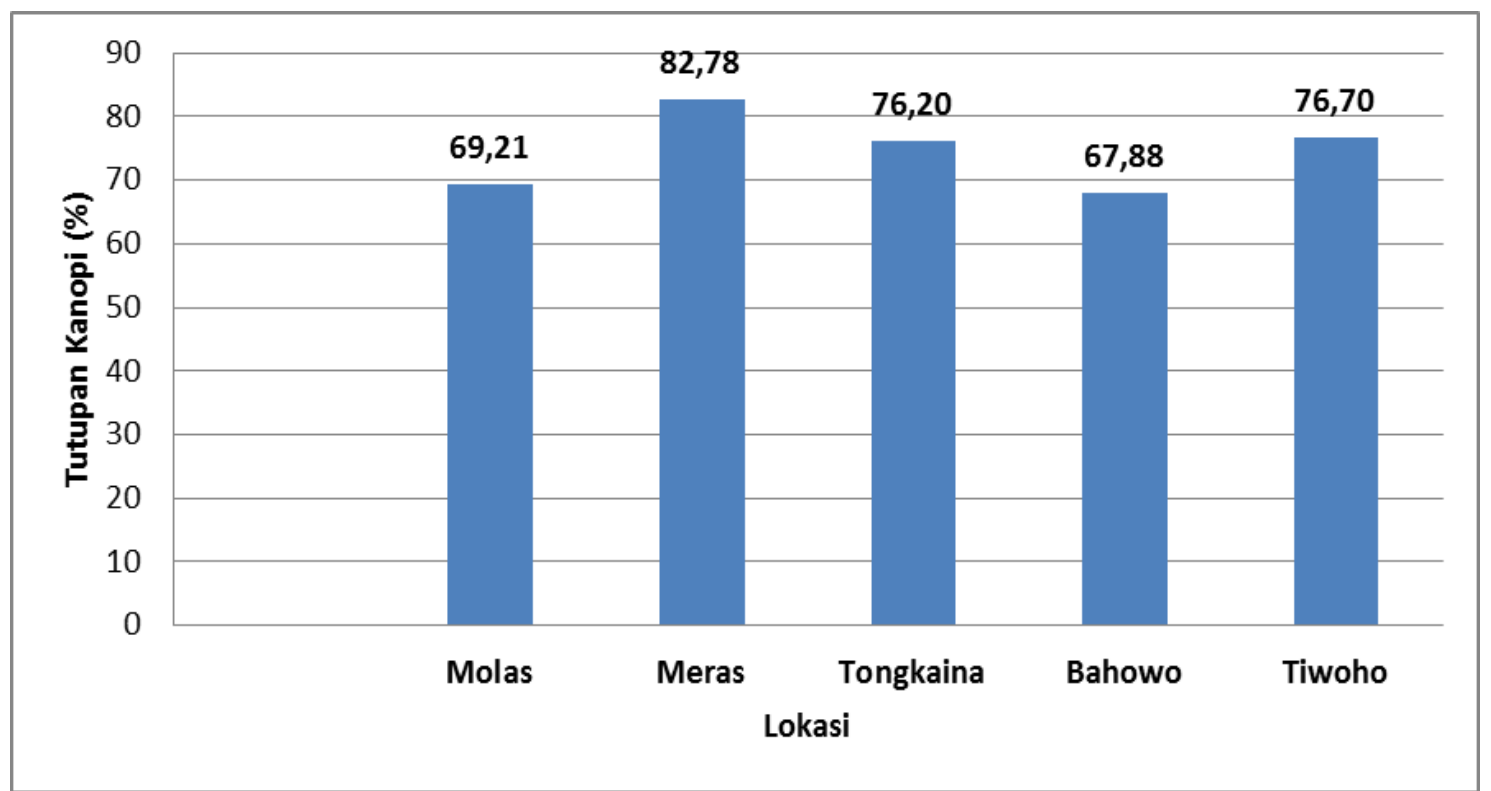

Gambar 6. Grafik perbandingan persentase tutupan kanopi (Anthoni et al., 2017)

Dari Gambar 6, dapat dilihat bahwa persentase tutupan kanopi mangrove berbanding lurus dengan kandungan karbon sedimen total disetiap lokasi, dimana persentase kanopi tertinggi terdapat di lokasi Meras dan persentase kanopi terendah terdapat di lokasi Bahowo.

\section{KESIMPULAN}

Dari penelitian yang telah dilakukan dapat disimpulkan bahwa:

1. Nilai densitas sedimen tanah berbeda pada masing-masing lapisan kedalaman disetiap lokasi. Nilai rata-rata densitas sedimen tanah tertinggi pada bagian depan terdapat pada lapisan kedalaman 60-100 cm, yaitu $0,78 \mathrm{~g} / \mathrm{cm}^{3}$. Pada bagian tengah terdapat pada lapisan kedalaman $60-100 \mathrm{~cm}$, yaitu 0,80 $\mathrm{g} / \mathrm{cm}^{3}$. Sedangkan pada bagian belakang terdapat pada lapisan kedalaman $0-30 \mathrm{~cm}$, yaitu 0,90 $\mathrm{g} / \mathrm{cm}^{3}$.

2. Nilai persentase karbon organik sedimen tanah diperoleh dari proses pengabuan bahan organik tanah. Nilai rata-rata persentase kandungan karbon organik tanah tertinggi pada titik bagian depan terletak di kedalaman $60-100 \mathrm{~cm}$, yaitu sebesar 20,61\%. Nilai tertinggi pada titik bagian tengah juga terdapat pada kedalaman 60-100 cm yaitu sebesar $22,01 \%$. Pada bagian belakang memiliki persentase tertinggi juga terdapat pada lapisan kedalaman 60-100 $\mathrm{cm}$, yaitu sebesar $16,18 \%$.

3. Nilai rata-rata kandungan karbon per kedalaman pada sedimen ekosistem mangrove di Pesisir Taman Nasional Bunaken bagian Utara berbeda. Pada titik bagian depan dan tengah hutan mangrove memiliki nilai rata-rata kandungan karbon tertinggi pada lapisan kedalaman 60-100 cm, yaitu masing-masing sebesar 160,37 $\mathrm{Mg} \mathrm{ha}^{-1}$ dan 178,26 Mg ha $^{-1}$. Sedangkan nilai rata-rata kandungan karbon pada bagian belakang memiliki nilai tertinggi pada lapisan kedalaman 0-30 cm yaitu sebesar 124,21 Mg ha-1. Nilai rata-rata kandungan karbon total tertinggi terletak pada Kelurahan Meras yaitu sebesar 
157,01 Mg ha-1 sedangkan paling sedikit terdapat pada Desa Bahowo yaitu sebesar 40,25 Mg $\mathrm{ha}^{-1}$.

\section{Ucapan Terima Kasih}

Program Demand Driven Research 2018 Coremap CTI Pusat Penelitian Oseanografi Lembaga IImu Pengetahuan Indonesia atas pelibatan dan bantuan dalam penelitian ini; Laboratorium Analisis Kesehatan, Politeknik Kesehatan kampus C, Manado atas waktu, tempat dan kesempatannya melakukan pengujian sampel hingga selesainya penelitian ini.

\section{DAFTAR PUSTAKA}

Alongi, D.M. 2012. Carbon Sequestration in Mangrove Forest. Carbon Management (3) : 313-322.

Analuddin, Jamili, Dafid, P. 2016. Ekspor Karbon Dari Serasah Daun Mangrove Di Taman Nasional Rawa Aopa Watumohai. Journal of Biological Research, 3(1): 321-327.

Anthoni, A., Schaduw, J.N.W., Sondak, C.F.A. 2017. Persentase Tutupan dan Struktur Komunitas Mangrove di Sepanjang Pesisir Taman Nasional Bunaken Bagian Utara. Jurnal Pesisir dan Laut Tropis. 2 (1).

Arif, A. 2013. Hutan Mangrove Fungsi dan Manfaatnya. Kanisius. Yogyakarta

Brown, S. 1997. Estimating Biomass and Biomass Change of Tropical Forest. Forestry Paper 134. USA: FAO.

Budiasih, Retnoayu., Supriharyono, Muskananfola, M.R. 2015. Analisis Kandungan Bahan Organik, Nitrat, Fosfat Pada Sedimen Di Kawasan Mangrove
Jenis Rhizophora Dan Avicennia Di Desa Timbulsloko, Demak. Journal Of Maquares Management Of Aquatic Resources. FPIK Universitas Diponegoro. Vol. 4 (3), Hal: 6675.

Dewanti, N.P., Muslim., Prihatiningsih, W.R. 2016. Analisis Kandungan Karbon Organik Total (KOT) Dalam Sedimen Di Perairan Sluke Kabupaten Rembang. Jurnal Oseanografi. Fakultas Perikanan dan IImu Kelautan. Universitas Diponegoro. Vol. 5 (2) : 202-210.

Dien, A.M.H., Rembet, U.N.W.J., Wantasen, A. 2015. Profil Ekosistem Mangrove Di Desa Bahoi Kabupaten Minahasa Utara. Jurnal IImiah Platax. Universitas Sam Ratulangi. Vol. 3:(2). ISSN: 2302-3589.

Donato D.C., Kauffman J.B., Mackenzie R.A., Ainsworth A, Pfleeger A.Z. 2012. Whole-island carbon stocks in the tropical Pacific: implication for mangrove conservation and upland restoration. Journal of Environmental Management. 97: 89-96.

Edwin, Muli. 2016. Penilaian Stok Karbon Tanah Organik Pada Beberapa Tipe Penggunaan Lahan Di Kutai Timur, Kalimantan Timur. Jurnal AGRIFOR. 15 (2).

Febriawan, E.N., Pratomo, Arief., Zulfikar, Andy. 2014. Jenis dan Karakteristik Sedimen di Daerah Mangrove Perairan Teluk Antang Kecamatan Siantan Kabupaten Kepulauan Anambas. Skripsi. FIKP Universitas Maritim Raja Ali Haji.

Gunarto. 2004. Konservasi Mangrove Sebagai Pendukung Sumber 
Hayati Perikanan Pantai. Jurnal Litbang Pertanian. 23(1):15-21.

Heriyanto, N.M. dan Subiandono, E. 2016. Peran Biomassa Mangrove Dalam Menyimpan Karbon di Kubu Raya, Kalimantan Barat. Jurnal Analisis Kebijakan. 13 (1) :1-12.

Indriyanto. 2006. Ekologi Hutan. Jakarta: Penerbit PT Bumi Aksara.

JGOFS. 2001. Biogeokimia Laut Dan Perubahan Global. International Geosphere -Biosphere Programme. Penelitian Perubahan Global Dari Dewan Internasional Untuk IImu Pengetahuan : Stockholm, Swedia. Pusat Teknologi Lingkungan BPPT.

Kordi, MGH. 2012. Ekosistem Mangrove; Potensi, Fungsi, dan Pengelolaan. Jakarta: Rineka Cipta.

Latifah, A.N., Fauzi, A.P., Amaliya, D., Memiasih, N., Sueb. 2013. Comparison of 4RSC Strategy For Solid Waste Management At Universitas Negeri Malang. Department of Biology. Faculty of Mathematics and Natural Sciences. Universitas Negeri Malang.

Lestari. 2016. Pendugaan Simpanan Karbon Organik Ekosistem Mangrove Di Areal Perangkap Sedimen-Pesisir Cagar Alam Pulau Dua Banten. Tesis. Sekolah Pasca Sarjana. IPB.

Mahasani G, Nuryani W, Wayan K. 2015. Estimasi Persentase Karbon Organik Di Hutan Mangrove Bekas Tambak, Perancak, Jembrana, Bali. Journal of Marine and Aquatic Sciences. 1:14-18.

Mahasani G, Karang W, Hendrawan G. 2016. Karbon Organik Di Bawah Permukaan Tanah Pada
Kawasan Rehabilitasi Hutan Mangrove, Taman Hutan Raya Ngurah Rai, Bali. Prosiding Seminar Nasional Kelautan Universitas Trunojoyo Madura. Faculty of Marine Science and Fisheries, Udayana University. Bali.

Manuri S, Putra C, Saputra A. 2011. Tehnik Pendugaan Cadangan Karbon Hutan. Merang REDD Pilot Project (MRPP). Palembang

Murdiyarso D, Donato D, Kauffman JB, Kurnianto S, Stidham M, Kanninen M. 2009. Carbon Storage In Mangrove And Peatland Ecosystems. Center for International Forestry Research (CIFOR).

Nofitasari, S., Koenawan, C.J., Syakti, A.D. 2017. Kontribusi Karbon Organik Pada Tekstur Sedimen Di Ekosistem Lamun (Enhalus acoroides) Pada Perairan Batu Licin dan Perairan Teluk Bakau Kabupaten Bintan. Fakultas IImu Kelautan dan Perikanan. Universitas Maritim Raja Ali Haji.

Paruntu, C.P., Windarto, A.B., Mamesah, Movrie. 2016. Mangrove dan Pengembangan Silvofishery Di Wilayah Pesisir Desa Arakan Kecamatan Tatapaan Kabupaten Minahasa Selatan Sebagai Iptek Bagi Masyarakat. Jurnal LPPM Bidang Sains dan Teknologi. 3 (2).

Prayitno, M.B., Sabaruddin, Setyawan, D., Yakup. 2013. Pendugaan Cadangan Karbon Gambut Pada Agroekosistem Kelapa Sawit. Jurnal Agrista. 17 (3).

Rahmadi, Puji dan Puspasari, Reny. 2015. Dinamika Ekologi Laut Sulawesi (WPP716) Sebagai Daya Dukung Terhadap Perikanan Malalugis 
(Decapterus macarellus Cuvier, 1833). Pusat Penelitian Pengelolaan Perikanan dan Konservasi Sumber Daya Ikan. Jurnal Literatur Perikanan Indonesia. Vol. 21 (2).

Restu, N.A., Agustin, R., Terry, L., Nasir, S., Mariska, A., August, D., Devi, D.S., Yusmiana, P., Peter, M., Andreas, H. 2013. Karbon Stok dan Struktur Komunitas Mangrove Sebagai Blue Carbon di Tanjung Lesung, Banten. Pusat Penelitian dan Pengembangan Sumberdaya Pesisir \& Laut.

Sasawu, J., Kusen, J.D., Schaduw, J.N.W. $2016 . \quad$ Struktur Komunitas Mangrove Di Kelurahan Tongkaina Manado. Jurnal Pesisir dan Laut Tropis. 2 (1).

Schaduw, J.N.W. 2015. Keberlanjutan Pengelolaan Ekosistem Mangrove Pulau Mantehage, Kecamatan Wori, Kabupaten Minahasa Utara Provinsi Sulawesi Utara. Jurnal LPPM Bidang Sains dan Teknologi. Universitas Sam Ratulangi. Vol. 2 (2).

Setyawan, A.D., Winarno, K., Purnama, PC. 2003. Ekosistem Mangrove di Jawa: 1. Kondisi terkini. Biodiversitas 2 (4):133-145.

Sondak, C.F.A. 2015. Estimasi Potensi Penyerapan Karbon Biru (Blue Carbon) Oleh Hutan Mangrove Sulawesi Utara. Journal Of Asean Studies on Maritime Issues. 1(1).

Suryono, S.N., Wibowo, E., Ario, R., Rozy, E.F. 2018. Estimasi Kandungan Biomassa dan Karbon di Hutan Mangrove Perancak Kabupaten Jembrana, Provinsi Bali. Buletin Oseanografi Marina. Fakultas Perikanan dan IImu Kelautan.
Universitas Diponegoro. 7(1): 1-8.

Syukri, Muhammad. 2017. Estimasi Cadangan Karbon Vegetasi Mangrove Hubungannya Dengan Tutupan Kanopi di Ampallas, Kelurahan Bebanga, Kecamatan Kalukku Kabupaten Mamuju Sulawesi Barat. Skripsi. Fakultas IImu Kelautan dan Perikanan. Universitas Hasanuddin. 